\title{
Triglycerides and high-density lipoprotein cholesterol are associated with insulinemia in adolescents
}

\author{
Guadalupe Ramírez-López, MSc, ${ }^{(1)}$ Clicerio González-Villalpando, MD, FACP,(2) Jorge Salmerón, DSc, ${ }^{(3)}$ \\ Manuel González-Ortiz, PhD, ${ }^{(4)}$ Victoria Valles-Sánchez, PhD. ${ }^{(5)}$
}

\author{
Ramírez-López G, González-Villalpando C, Salmerón J, \\ González-Ortiz M,Valles-Sánchez V. \\ Triglycerides and high-density lipoprotein cholesterol are \\ associated with insulinemia in adolescents. \\ Salud Publica Mex 2006;48:293-299.
}

\begin{abstract}
Objective. The aim of this study was to evaluate the association between lipids and insulin concentration in adolescents. Material and Methods. A cross-sectional study of 350 adolescents aged 14-19 years old from a public high school in Guadalajara, in the state of Jalisco, Mexico, was conducted. Fasting insulin concentration was determined using microparticle enzyme immunoassay; total cholesterol and triglycerides were detected by standard enzymatic procedures; and low- and high-density lipoproteins were found using standard precipitation methods. Statistical analysis included linear multivariate regression. Results. Serum triglycerides were associated positively with insulin fasting $(\beta=$ $0.003, p=0.000 \mathrm{I}$ ) and high-density lipoprotein cholesterol was negatively associated with insulin fasting in male adolescents I $8-19$ years old $(\beta=-0.03, p=0.012)$. Conclusions. The relationships between triglycerides and insulin and between high-density lipoprotein cholesterol and insulin are already present in adolescence.
\end{abstract}

Key words: triglycerides, high-density lipoprotein cholesterol, lipids, insulin, obesity, adolescents, Mexico
Ramírez-López G, González-Villalpando C, Salmerón J, González-Ortiz M, Valles-Sánchez V.

Triglicéridos y colesterol de lipóproteína de alta densidad asociados con insulina en adolescentes. Salud Publica Mex 2006;48:293-299.

\section{Resumen}

Objetivo. Evaluar la relación entre lípidos e insulina en adolescentes. Material y métodos. Estudio transversal en 350 adolescentes de 14 a 19 años de preparatoria pública en Guadalajara, Jal., México. La insulina se midió por inmunoensayo enzimático de micropartícula, el colesterol total y triglicéridos por pruebas enzimáticas estándares, y las lipoproteínas de baja y alta densidad por métodos de precipitación. Se utilizó análisis de regresión lineal multivariada. Resultados. Los triglicéridos se asociaron en forma positiva con insulina $(\beta=0.003, p=0.000 \mathrm{I})$ y la lipoproteína de alta densidad se asoció en forma negativa con insulina en varones de $18-19$ años de edad $(\beta=-0.03, p=0.012)$. Conclusiones. En los adolescentes, los triglicéridos y las lipoproteínas de alta densidad están asociados con la insulinemia.

Palabras claves: triglicéridos; lipoproteínas de alta densidad; lípidos; insulina; obesidad; adolescentes, México

(I) Unidad de Investigación Epidemiológica y en Servicios de Salud del Adolescente, Instituto Mexicano del Seguro Social (IMSS), Guadalajara, Jal., México.

(2) Centro de Estudios en Diabetes AC, American British Cowdray Medical Center; Centro de Investigación en Salud Poblacional, Instituto Nacional de Salud Pública, México D.F., México.

(3) Unidad de Investigación Epidemiológica y en Servicios de Salud, IMSS, Cuernavaca, Mor., México.

(4) Unidad de Investigación en Epidemiología Clínica, IMSS, Guadalajara, Jal., México.

(5) Departamento de Endocrinología, Instituto Nacional de Ciencias Médicas y Nutrición Salvador Zubirán, México D.F., México.

Received on: March 7,2006 • Accepted on: April 17, 2006

Address reprint request to: Mtra. Guadalupe Ramírez-López, Unidad de Investigación Epidemiológica y en Servicios de Salud del Adolescente, Instituto Mexicano del Seguro Social, Paseo de Rosa Morada 205, Pinar de la Venta, 45220 Zapopan, Jal. México.

E-mail: maria.ramirezlo@imss.gob.mx 
$\mathrm{T}$ ype 2 diabetes and cardiovascular disease are the leading causes of mortality in Mexico. ${ }^{1}$ Both appear to begin early in life. ${ }^{2,3}$ Considering the recent findings of high incidence of type 2 diabetes in the Mexican population, the problem is likely to reach more serious proportions. ${ }^{4}$ Moreover, it has been shown that type 2 diabetes incidence in adolescents has increased in recent years and a higher prevalence of metabolic syndrome has been shown among Mexican-American adolescents. ${ }^{5,6}$

Hyperinsulinemia is the strongest predictor for type 2 diabetes and is associated with lipid-profile abnormalities. ${ }^{7}$ Obesity is related with hyperinsulinemia and altered lipid and lipoprotein concentrations in adults, especially in those with abdominal fat distribution. ${ }^{8}$ Insulin, lipid, and lipoprotein concentrations might be altered by environmental as well as genetic factors. ${ }^{9}$ In adults, triglycerides, low-density lipoprotein cholesterol (LDL), and very-low-density lipoprotein cholesterol (VLDL) are positively associated with insulin resistance, while high-density lipoprotein cholesterol (HDL) is negatively associated with insulin resistance. ${ }^{6,10-12}$

Hyperinsulinemia, obesity, and lipid and lipoprotein metabolism abnormalities may be present during adolescence and may persist through adulthood, at which time they contribute to the establishment of metabolic syndrome and eventually influence the development of diabetes along with cardiovascular risks later in life. ${ }^{3,13}$ The higher concentrations of insulin, lipids, and lipoproteins observed during early adolescence as compared with late adolescence are explained mainly by pubertal growth spurt related insulin secretion increases. ${ }^{14}$ The association among insulin, lipids, and lipoproteins during this period of life is not completely understood. There is controversy concerning this matter, as some researchers have found that triglycerides are positively associated with insulin, whereas others have also found associations with LDL, HDL, and VLDL. ${ }^{15-17}$ Total cholesterol has not been associated with insulin. ${ }^{15-17}$ Furthermore, the association between insulin, abdominal fat, blood lipids, and lipoproteins in adolescents is not as clear as it is in adults. ${ }^{18,19}$

The aim of this study was to determine the relationship among lipids, lipoprotein profile, and fasting insulin concentration, as well as the relationships between lipids, lipoproteins, insulin, and abdominal obesity in adolescents, as evaluated by waist circumference (WC) and waist-to-hip-ratio (WHR).

\section{Material and Methods}

Subjects. The relationship among lipids, lipoprotein profile, insulin, and obesity in adolescents was investigated using a cross-sectional study. Recruitment and data collection were carried out from October 1998 to March 1999. Methods and procedures pertinent to this study have been reported previously. ${ }^{20}$ Briefly, 350 adolescents -113 boys and 237 girls- were randomly recruited from 10th to 12th-grade classes at a state-funded Mexican high school in the Jalisco state capital of Guadalajara. Within the sample, $45.4 \%$ of adolescents were classified as high socioeconomic status, $33.4 \%$ as middle, and $21.1 \%$ as low. Adolescents who worked comprised $27.0 \%$ of the sample. Both adolescents and parents gave written informed consent in accordance with the Institutional Review Board of the Instituto Mexicano del Seguro Social (Mexican Institute of Social Security) in Guadalajara.

Main outcome measurements. Fasting blood samples were obtained for serum lipid, lipoprotein, and insulin determinations after $12 \mathrm{~h}$. Serum samples were stored frozen at $-25^{\circ} \mathrm{C}$ until analyzed. Serum insulin was determined based on microparticle enzyme immunoassay using anti-insulin (mouse-monoclonal)-coated microplates. ${ }^{21}$ Regarding lipids and lipoproteins, total serum cholesterol and triglycerides were determined by standard enzymatic procedures, ${ }^{22,23}$ while LDL and HDL were determined using standard precipitation methods with polyvinyl sulphate and phosphotungstic acid, respectively. ${ }^{24,25} \mathrm{~A}$ BM analyzer (Hitachi 705, Indianapolis, IN, USA) was used for all assays. VLDL was estimated according to the following equation: VLDL= total cholesterol -(HDL + LDL). Intra- and interassay variation coefficients were 4.0 and $6.2 \%$ for insulin and $<2.7$ and $<3.7 \%$ for all lipids, respectively.

A systematic physical examination was performed on all study participants, and body weight, height and waist and hip circumference measurements were assessed according to standardized protocols. ${ }^{26}$ Overweight was defined as body mass index (BMI, $\mathrm{kg} / \mathrm{m}^{2}$ ) for age $\geq 85$ th percentile. Unfavorable abdominal fat distribution was defined as a WHR $\geq 0.85$ for females and $\geq 0.94$ for males. ${ }^{27}$

In addition, a validated 7-day physical-activity recall questionnaire was administered by a trained dietitian. ${ }^{28}$ Activities were classified according to metabolic equivalents (METS) (ratio of working metabolic rate/resting metabolic rate). Energy expenditure (EE) was estimated as follows: $\mathrm{kcal} / \mathrm{day}=\sum$ [weight 
$(\mathrm{kg})^{*}$ METS *min/h)/7]. ${ }^{29}$ To assess energy and lipid intake, a validated semi-quantitative food-frequency questionnaire was administered containing 124 items. $^{30}$ Average daily energy and lipid intake were derived using the System of Nutritional Habits and Nutrients Intake (SNUT) evaluation program. ${ }^{31}$ Socioeconomic status, family history of type 2 diabetes, and smoking status were assessed using a standardized questionnaire.

Statistical analysis. Descriptive analysis was performed to estimate the study population's clinical and anthropometric characteristics; results are expressed as mean \pm standard deviation $(\bar{X} \pm S D)$ or as percentages. Differences between means were obtained with the Student $t$ test for continuous variables and proportions were compared using a $\chi^{2}$ test. Partial correlation coefficients were computed to determine any correlation among serum lipids, lipoproteins, and insulin, adjusted for age and sex. Adjusted blood lipids and lipoprotein means were obtained across anthropometric variables (BMI, WC, and WHR). Confounders included age, sex, BMI, WC, EE, caloric intake, and smoking status. Linear trend was tested with multivariate analysis. Adjusted means of lipid and lipoprotein concentrations according to insulin quartiles were also obtained and tested for linear trend after performing multivariate analysis. Due to the skewed distribution of insulin, this was log-transformed for analysis. The association among fasting lipid, lipoprotein, and insulin concentration was assessed using multiple linear regression analysis. A model was built for each lipid and lipoprotein, with insulin as the dependent variable. The inflation factor was analyzed in order to evaluate possible multicollinearity among studied variables. Data were analyzed with Stata version 7.0 software (Stata Corp., TX, USA). Differences were regarded as statistically significant if corresponding $p$ values were $\leq 0.05$.

\section{Results}

The study population consisted of 350 adolescents, $68 \%$ female, with a mean age of $16 \pm 1.19$ years (range, 1419 years old). Nineteen percent of all adolescents were overweight, $3 \%$ had unfavorable abdominal fat distribution, $22 \%$ were current smokers, and $8.3 \%$ had a family history of type 2 diabetes. Mean fasting serum insulin concentration was $54.8 \pm 29.4 \mathrm{pmol} / \mathrm{l}$; triglycerides, $100.3 \pm 35.4 \mathrm{mg} / \mathrm{dl}$; total cholesterol (CHOL), $157.2 \pm 27.0 \mathrm{mg} / \mathrm{dl} ; \mathrm{LDL}, 95.2 \pm 26.3 \mathrm{mg} / \mathrm{dl} ; \mathrm{VLDL}, 18.5$ $\pm 7.3 \mathrm{mg} / \mathrm{dl}$; and HDL, $43.5 \pm 8.9 \mathrm{mg} / \mathrm{dl}$. Lipid and lipoprotein profile distribution by sex and socioeconomic status in this population has been reported elsewhere. $^{32}$

Under partial correlation analysis adjusting for age and sex, fasting insulin concentration correlated positively with lipids and lipoproteins, except VLDL, and correlated negatively with HDL. BMI and WC correlated positively with insulin, lipids, and lipoproteins, and negatively with HDL. BMI showed strongest correlations for nearly all parameters, WHR also correlated positively with all these parameters except total cholesterol and LDL, and WC showed stronger correlations with these parameters in comparison with WHR (Table I).

Linear trend results of lipids and lipoproteins across anthropometric parameters demonstrated that total cholesterol, triglycerides, and LDL increased from the lowest to the highest BMI quartile (147.7-168.5 $\mathrm{mg} / \mathrm{dl}, p=0.02,91.2-118.4 \mathrm{mg} / \mathrm{dl}, p=0.008$, and 85.2-

Table I

AGE- AND GENDER-ADJUSTED CORRELATION COEFFICIENTS AMONG INSULIN, LIPID AND LIPOPROTEIN PROFILE, AND ANTHRopometric parameters in adolescents in Guadalajara, Jalisco, MeXico I998- 1999 ( $=350$ )

\begin{tabular}{|c|c|c|c|c|c|c|c|c|}
\hline Characteristic & $\begin{array}{l}\text { Insulin } \\
\text { (pmolll) }\end{array}$ & $\begin{array}{l}\text { Cholesterol } \\
\text { (mg/dl) }\end{array}$ & $\begin{array}{l}\text { Triglycerides } \\
\text { (mg/dl) }\end{array}$ & $\begin{array}{l}\text { LDL } \\
(m g / d l)\end{array}$ & $\begin{array}{l}V L D L \\
(m g / d l)\end{array}$ & $\begin{array}{l}H D L \\
(\mathrm{mg} / \mathrm{dl})\end{array}$ & $\begin{array}{c}H D \\
L D L /((m g / d l) /(m g / d l))\end{array}$ & $\begin{array}{c}\mathrm{CHOL/HDL} \\
((\mathrm{mg} / \mathrm{dl}) /(\mathrm{mg} / \mathrm{dl}))\end{array}$ \\
\hline Insulin (pmol/l) & & $0.207^{*}$ & $0.357^{*}$ & $0.259 *$ & 0.099 & $-0.23 *$ & $0.343 *$ & $0.363 *$ \\
\hline Body mass index $\left(\mathrm{kg} / \mathrm{m}^{2}\right)$ & $0.610^{*}$ & $0.187 *$ & $0.377^{*}$ & $0.250^{*}$ & $0.118^{\ddagger}$ & $-0.273 *$ & $0.352 *$ & $0.383 *$ \\
\hline Waist circumference $(\mathrm{cm})$ & $0.587^{*}$ & $0.152^{\S}$ & $0.383 *$ & $0.216^{*}$ & $0.145^{\S}$ & $-0.295^{*}$ & $0.340^{*}$ & $0.38 I^{*}$ \\
\hline Waist-to-hip ratio $(\mathrm{cm} / \mathrm{cm})$ & $0.386 *$ & 0.029 & $0.28 I^{*}$ & 0.099 & $0.112^{\ddagger}$ & $-0.28 I^{*}$ & $0.247^{*}$ & $0.288 *$ \\
\hline $\begin{array}{l}* p<0.0001 \\
\ddagger p<0.05 \\
\S p<0.01\end{array}$ & & & & & & & & \\
\hline
\end{tabular}

LDL (low-density lipoprotein cholesterol); VLDL (very low-density lipoprotein cholesterol); HDL (high-density lipoprotein cholesterol); LDL/HDL (lowdensity lipoprotein cholesterol /high-density lipoprotein cholesterol ratio; CHOL/HDL (total cholesterol/high-density lipoprotein cholesterol ratio) 
$105.6 \mathrm{mg} / \mathrm{dl}, p=0.02$, respectively). Triglycerides increased from the lowest to the highest WC quartile (97.6-114.5 mg/dl, $p=0.046$ ), while HDL decreased from the lowest to the highest WHR quartile (47.1-39.9 $\mathrm{mg} / \mathrm{dl}, p<0.001)$.

Table II shows median values of fasting lipid and lipoprotein concentrations according to insulin quartiles after adjustment for known confounders. After conducting multivariate regression analysis as well as a trend test run for each lipid and lipoprotein, only triglycerides were found to increase across insulin quartiles from lowest to highest $(93.1 \mathrm{mg} / \mathrm{dl}-110.4$ $\mathrm{mg} / \mathrm{dl}, p=0.043)$.

Total cholesterol, triglycerides, LDL, VLDL, and $\mathrm{HDL}$, and total $\mathrm{CHOL} / \mathrm{HDL}$ ratio were associated with insulin after adjustment for age and sex. However, the relationship among insulin and total cholesterol, LDL, VLDL, and HDL was not statistically significant when BMI was included in the model. Moreover, when WC was included triglycerides and CHOL/LDL ratio remained independently associated with insulin concentration. Finally, when EE was included in the model only triglycerides were associated with insulin concentration (Table III).

When no significance was found in the model adjusted by age, sex, BMI, WC, and EE, additional multiple linear analyses were performed by age group (14-15, 16-17, and 18-19 years) and sex (male and female). These analyses demonstrated a significant relationship between insulin and HDL in males 18-19 years old when $\operatorname{BMI}(\beta=-0.03, p=0.012), \mathrm{WC}(\beta=-0.03, p=0.009)$, and EE $(\beta=-0.03, p=0.02)$ were included. The variance inflation
Table II

AdJUSTED MEANS* OF FASTING LIPID AND LIPOPROTEIN CONCENTRATIONS ACCORDING TO INSULIN QUARTILES in adolescents in Guadalajara, Jalisco, Mexico, 1998-1999 $(N=350)$

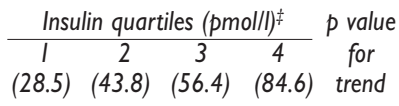

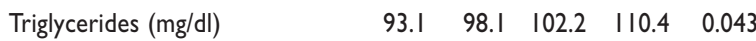

\begin{tabular}{lllllll}
\hline Total cholesterol $(\mathrm{mg} / \mathrm{dl})$ & 156.0 & 153.5 & 159.0 & 160.9 & 0.381 \\
\hline
\end{tabular}

\begin{tabular}{llllll}
\hline $\mathrm{LDL}(\mathrm{mg} / \mathrm{dl})$ & 94.8 & 91.9 & 95.3 & 98.5 & 0.521 \\
\hline $\mathrm{VLDL}(\mathrm{mg} / \mathrm{dl}$ & 17.7 & 18.0 & 18.7 & 19.7 & 0.453
\end{tabular}

\begin{tabular}{lllllll}
\hline $\operatorname{VLDL}(\mathrm{mg} / \mathrm{dl})$ & 17.7 & 18.0 & 18.7 & 19.7 & 0.453 \\
\hline
\end{tabular}

\begin{tabular}{lrrrrr}
\hline $\mathrm{HDL}(\mathrm{mg} / \mathrm{dl})$ & 43.7 & 43.7 & 44.6 & 42.3 & $0.5 \mathrm{II}$ \\
\hline
\end{tabular}

\begin{tabular}{lllllll}
\hline $\mathrm{CHOL} / \mathrm{HDL}$ ratio $((\mathrm{mg} / \mathrm{dl}) /(\mathrm{mg} / \mathrm{dl}))$ & 3.7 & 3.6 & 3.7 & 3.9 & 0.249
\end{tabular}

\begin{tabular}{lllllll}
\hline LDL/HDL ratio $((\mathrm{mg} / \mathrm{dl}) /(\mathrm{mg} / \mathrm{dl}))$ & 2.3 & 2.2 & 2.2 & 2.4 & 0.340
\end{tabular}

\footnotetext{
* Adjusted by age (years), body mass index $\left(\mathrm{kg} / \mathrm{m}^{2}\right)$, waist circumference $(\mathrm{cm})$, energy intake (kcal/day), saturated fat intake (g/day), monosaturated fat intake ( $g /$ day), polyunsaturated fat intake ( $g /$ day), energy expenditure (kcal/day), smoking (none, I- 100 and $>100$ cigarettes per year), gender (female/male), and family history of type 2 diabetes (yes or no). Insulin quartile median values are depicted in parentheses

‡ Values are insulin quartile medians
}

factor was 3.8 and no problems were detected for multicollinearity. These associations were not statistically significant in younger adolescents.

Table IV shows the relationship between serum triglycerides and insulin, adjusted for socioeconomic and environmental factors. Triglycerides were associated with fasting insulin concentration $(\beta=0.003$,

Table III

RELATIONSHIP AMONG LIPID, LIPOPROTEIN, AND INSULIN CONCENTRATIONS AFTER ADJUSTMENT FOR CONfOUNDing factors in Adolescents in Guadalajara, Jalisco, MeXico, I $998-$ I 999 ( $N=348)$

\begin{tabular}{|c|c|c|c|c|c|}
\hline & & & & & \\
\hline & Age & Age, sex & Age, sex, $B M I^{\ddagger}$ & Age, sex, BMI,WC $\S$ & Age, sex, BMI,WC, EE \\
\hline Triglycerides (mg/dl) & $0.006^{\&}$ & $0.006^{\&}$ & $0.003^{\&}$ & $0.003^{\&}$ & $0.003^{\&}$ \\
\hline Total cholesterol $(\mathrm{mg} / \mathrm{dl})$ & $0.004^{\&}$ & $0.004^{\&}$ & 0.001 & 0.001 & 0.002 \\
\hline$\overline{\mathrm{LDL}}(\mathrm{mg} / \mathrm{dl})$ & $0.004^{\&}$ & $0.004^{\&}$ & 0.001 & 0.001 & 0.001 \\
\hline VLDL (mg/dl) & $0.010^{2}$ & $0.010^{*}$ & 0.004 & 0.004 & 0.004 \\
\hline$\overline{\mathrm{HDL}}(\mathrm{mg} / \mathrm{dl})$ & $-0.012^{\&}$ & $-0.013^{\&}$ & -0.004 & -0.001 & -0.001 \\
\hline 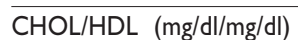 & $0.191^{\&}$ & $0.191^{\&}$ & $0.068^{7}$ & $0.064^{z}$ & 0.048 \\
\hline$\overline{\mathrm{LDL} / \mathrm{HDL}(\mathrm{mg} / \mathrm{d} / \mathrm{mg} / \mathrm{dl})}$ & $0.185^{\&}$ & $0.185^{\&}$ & $0.063^{*}$ & 0.060 & 0.044 \\
\hline
\end{tabular}

* Results (b coefficients) for linear multivariate regression after adjustment for factors listed

¥ BMI: body mass index

$\S$ WC: waist circumference

\# EE: energy expenditure

$\&<0.01$

$\neq<0.05$ 


\begin{tabular}{|c|c|c|c|}
\hline \multicolumn{4}{|c|}{$\begin{array}{l}\text { RELATIONSHIP BETWEEN SERUM TRIGLYCERIDES } \\
\text { AND INSULIN IN ADOLESCENTS IN GUADALAJARA, } \\
\text { JALISCO, MEXICO, I998-1999 (N=348)* }\end{array}$} \\
\hline dictors & $\beta$ & $95 \% \mathrm{Cl}$ & $p$ value \\
\hline riglycerides (mg/dl) & 0.00267 & $0.0012, \quad 0.0041$ & $<0.0001$ \\
\hline Body mass index $\left(\mathrm{kg} / \mathrm{m}^{2}\right)$ & 0.07582 & $0.0401,0.1116$ & $<0.0001$ \\
\hline Waist circumference $(\mathrm{cm})$ & 0.01586 & $0.0007, \quad 0.0310$ & 0.040 \\
\hline Energy expenditure (kcal/day) & -0.00038 & $-0.0005,-0.0002$ & $<0.0001$ \\
\hline Energy intake (kcal/day) & 0.00001 & $-0.000 I, \quad 0.000 \mathrm{I}$ & 0.800 \\
\hline \multicolumn{4}{|c|}{$\begin{array}{l}\text { * Results of multivariate linear regression }[R 2=0.4 \mathrm{I}, \mathrm{F}=14.23] \text {. Adjusted } \\
\text { for age (years), sex (female/male), family history of diabetes (yes } / \text { no), } \\
\text { cigarette smoking categories (never, I-20,5I-100, } 10-250,>250 \text { cigarettes } \\
\text { per year), saturated fat }(\mathrm{g} / \mathrm{day}) \text {, monosaturated fat (g/day), and } \\
\text { polyunsaturated fat }(\mathrm{g} / \mathrm{day}) .95 \% \mathrm{Cl}\end{array}$} \\
\hline
\end{tabular}

$p<0.01)$. BMI and WC were positively associated with fasting insulin concentration $(\beta=0.076, p<0.01$ and $\beta=$ $0.016, p=0.04$, respectively). This model explained $41 \%$ of the plasma fasting insulin concentration variability. The variance inflation factor was 4.2 and no problems were detected for multicollinearity.

\section{Discussion}

The findings of this study suggest that insulin resistance syndrome factors are already present in adolescence and, as demonstrated in adult studies, triglyceridemia, HDL, and obesity are related with insulinemia independently of other relevant factors. The results show that hyperinsulinemia correlates negatively with HDL and positively with total cholesterol, triglycerides, LDL, and the CHOL/HDL ratio, after age and sex adjustments. A further adjustment including BMI, WC, EE and smoking status was carried out. With the exception of triglycerides and HDL in 18-19-year-old male adolescents, associations among insulin, lipids, and lipoproteins disappeared. These results are similar to those reported by Bonora et al., ${ }^{15}$ except that those authors found no association with HDL. Other studies have found that insulin resistance is also related with LDL and VLDL, ${ }^{16,17}$ but these associations may have been confounded because BMI, WC, and EE were not controlled. Moreover, adolescents in those studies were younger than adolescent participants in the study presented here, which also may have contributed to the differences. Although only triglycerides and HDL in males aged 18-19 years were significantly associated with insulin in this study, it is important to point out the tendency toward higher fasting insulin with ad- verse lipid or lipoprotein concentration, as observed in Table II. Although some metabolic alterations persist from adolescence to young adulthood, ${ }^{33}$ the possible biological implications for late adulthood of tendencies observed in the adolescents representative of this study are yet to be established.

During adolescence, insulin, lipid, and lipoprotein concentrations change according to sex and puberty. ${ }^{14,33-34}$ Although puberty was not evaluated in this study, it is assumed that adolescents are mainly at Tanner stages 4 and 5 , because in other series it has been found that $56 \%$ of 14 - to 19 -year-old adolescents from Guadalajara were at Tanner stage 4 and $42 \%$ at Tanner stage 5 (unpublished data). Total cholesterol and LDL were not associated with insulin probably because of total cholesterol decreases during Tanner stages 4 and $5,34,35$ possibly due to the effect of steroid hormone increases. For example, in this study, total cholesterol values fell from 165.5 in $14-15$ years old to $157.6 \mathrm{mg} / \mathrm{dl}$ in 18-19 years old females. The same pattern occurred with LDL which decreased from 102.4-92.4 mg/dl in 14-15 years old to $92.4 \mathrm{mg} / \mathrm{dl}$ in $18-19$ years old. ${ }^{32}$

One interesting finding in this study comprised the negative association between HDL and insulin, particularly in 18-19-year-old males compared with younger males or females. These results differ from the results of a study of 18-year-old healthy young men in Italy in which HDL was not associated negatively with insulin. However, HDL concentration was higher in adolescents in that study than in those in the study presented here (53.7 vs. $36.3 \mathrm{mg} / \mathrm{dl}){ }^{15}$ This is probably due to the Italian adolescents' diet, which was rich in monosaturated fat. The present finding may suggest that atherogenesis development could be triggered at this young age, which warrants further investigation.

High abdominal fat may increase free fatty acid flux to the liver, thereby increasing its oxidation, modifying glucose disposal to extra-hepatic tissues, and increasing insulin resistance. ${ }^{36}$ This high free fatty acid flow to hepatocytes may modify the number of insulin receptors, alter receptor function, and modify insulin internalization and degradation. These effects may account for altered hepatic insulin extraction and sensitivity. ${ }^{37}$ It was expected that BMI, WC, and WHR would be independent predictors of serum insulin, as had been published, ${ }_{17,19}^{17}$ nevertheless, as demonstrated elsewhere ${ }^{15}$ this study found that only BMI and WC were independently associated. This study controlled for potential confounders, which might explain these discrepancies. Furthermore, lack of an association might be explained by the early development of abdominal fat deposits at this stage of life, or because WHR does not really capture visceral adiposity as it 
does in adults, in whom it was shown to be an important risk factor for insulin and lipid concentrations.

The relationship between serum insulin concentration and lipid and lipoprotein profile is better understood in adults than in adolescents. Perhaps there is a critical time-frame that could enable identification of an evolving dysfunctional metabolism. Improved understanding of several factors, including the genetics and physiology of puberty, would explain associations between lipids and insulin in adolescents. Due to the crosssectional design of this study, no causal relationship between triglycerides and insulin or between HDL and insulin can be established. However, the data in this study support the hypothesis that high triglyceride concentration, low HDL concentration, obesity, and abdominal fat may be independently associated with hyperinsulinemia. Future cohort studies and interventions in adolescents would be useful to establish causality between triglycerides and insulin, and HDL and insulin. Meanwhile, the results of this study suggest that it is important to initiate primary prevention programs to reduce, in adolescence, these risk factors for chronic diseases, such as type 2 diabetes mellitus.

\section{Acknowledgements}

We thank Dr. Caridad Leal (Surgery Research Division, CIBO, IMSS) for her laboratory assistance, and staff, pupils, and parents of the Preparatoria School 5 of the Universidad de Guadalajara, México, without whom this study would not have been possible.

This research was supported by grants SIMORELOS 970302017; IMSS-FP-0038/213; and CONACyT 96600.

\section{References}

I. Instituto Nacional de Estadística, Geografía e Informática/Secretaría de Salud. Dirección General de Información General en Salud. Base de datos de defunciones 2002. México: INEGI, 2004.

2. Berenson G, Radhakrishnamurthy B, Bao W, Srinivasan S. Does adultonset diabetes mellitus begin in childhood?:The Bogalusa Heart Study. Am J Med Sci 1995;310:Suppl I:S77-S82.

3. Zimmet P, Collins V, Dowse G, Knight LT. Hyperinsulinemia in youth is a predictor of type 2 (non-insulin-dependent) diabetes. Diabetologia 1993;35:534-54|.

4. Burke JP,Williams K, Haffner SM, González-Villalpando C, Stern MP. Elevated incidence of type 2 diabetes in San Antonio, Texas, compared with that of Mexico City, Mexico. Diabetes Care 200I;24:1573-1578. 5. Alberti G, Zimmet P, Shaw J, Bloomgarden Z, Kaufman F, Silinik M. Type 2 diabetes in the young: the evolving epidemic. The Intenational Diabetes Federation Consensus Workshop. Diabetes Care 2004;27(7): 1798-18I1.
6. Duncan Glen E, Li Sierra M, Zhuo Xiao-Hua. Prevalence and trends of a metabolic syndrome phenotype among U.S. Adolescents, 1999-2000. Diabetes Care 2004;27(I0):2438-2443.

7. DeFronzo R, Ferrannini E. Insulin resistance. A multifaceted syndrome responsible for NIDDM, obesity, hypertension, dyslipidemia, and atherosclerotic cardiovascular disease. Diabetes Care 1991;14:173-194. 8. Pouliot MC, Després JP, Lemieux S, Moorjani S, Bouchard C, Tremblay $A$, et al. Waist circumference and abdominal sagittal diameter: best simple anthropometric indexes of abdominal visceral adipose tissue accumulation and related cardiovascular risk in men and women. Am J Cardiol 1994;73:460-468.

9. Olfesky J, Nolan J. Insulin resistance and non-insulin-dependent diabetes mellitus: cellular and molecular mechanisms. Am J Clin Nutr 1995;6I Suppl:980S-986S.

10. Cigolini M, Seidell JC, Targher G, Deslypere JP, Ellsinger BM, Charzewska J, et al. Fasting serum insulin in relation to components of metabolic syndrome in European healthy men:The European Fat Distribution Study. Metabolism 1995;44:35-40.

II. Karhapaa P, Malkki M, Laakso M. Isolated low HDL cholesterol.An insulin-resistant state. Diabetes 1994;43:4 I I-4I7.

12. Garg A. Insulin resistance in the pathogenesis of dyslipidemia. Diabetes Care 1996;19:387-389.

13. Sinaiko AR, Donahue RP, Jacobs DR Jr, Prineas RJ. Relation of weight and rate of increase in weight during childhood and adolescence to body size, blood pressure, fasting insulin, and lipids in young adults. The Minneapolis Children's Blood Pressure Study. Circulation 1999;99: I47I-I476.

14. Arslanian S, Kalhna S. Correlation between fatty acid and glucose metabolism. Potential explanation of insulin resistance of puberty. Diabetes 1994;43:908-914

15. Bonora E, Targher G, Zenere MB, Saggiani F, Cacciatori V,Tosi F, et al. Relationship between fasting insulin and cardiovascular risk factors is already present in young men: the Verona Young Men Atherosclerosis Risk Factors Study. Eur J Clin Invest 1997;27:248-254.

16. Steinberger J, Moorehead C, Katch V, Rocchini AP. Relationship between insulin resistance and abnormal lipid profile in obese adolescents. J Pediatr 1995;126:690-695.

17. Moussa M, Shaltout AA, Nkansa-Dwamena D, Mourad M, AI-Sheikh $\mathrm{N}$, Agha $\mathrm{N}$, et al. Association of fasting insulin with serum lipids and blood pressure in Kuwaiti children. Metabolism 1998;47:420-424. 18. Chu N, Rimm E, Wang D, Liou H, Shieh S. Relationship between anthropometric variables and lipid levels among school children: The Taipei Children Heart Study. Int J Obes Relat Metab Disord 1998;22:66-72.

19. Freedman D, Serdula M, Srinivasan S, Berenson G. Relation of circumferences and skinfold thicknesses to lipid and insulin concentrations in children and adolescents: the Bogalusa Heart Study. Am J Clin Nutr 1999;69:308-317.

20. Ramírez-López G, González-Villalpando C, Sánchez-Corona J, Salmerón-Castro J, González-Ortiz M, Celis-de la Rosa A, et al.Weight, physical activity, and smoking as determinants of insulinemia in adolescents. Arch Med Res 2001;32:208-2I3.

2I.Tietz N. Clinical guide to laboratory tests. 2nd ed. Philadelphia:WB Saunders, 1990.

22. Siedel J, Hagele E, Ziegenhorn J,Wahlefeld A. Reagent for the enzymatic determination of serum total cholesterol with improved lipolytic efficiency. Clin Chem 1983;29:1075-1080.

23. Bergmeyer H. Methoden enzimatischen analyse. 3rd ed. Wenheim: Verlag Chemic, 1974.

24. Greten H, Lang P, Schettler G. Lipoproteine und Herzinfarkt. BadenBaden:Witzstrock-Verlag, 1979.

25. Burstein M, Scholnick H, Morfin R. Rapid method for the isolation of lipoproteins from human serum by precipitation with polyanions.J Lipid Res 1970; | 1:583-595. 
26. Lohman T, Roche A, Martorell R. Anthropometric Standardization Reference Manual. Champaign IL: Human Kinetics Books, 1988. 27. Casillas L,Vargas L. La distribución de grasa corporal, posible factor de riesgo para la salud. Cuadernos de Nutrición 1993;16:7-15.

28. Sallis J, Buono M, Roby J, Micale F, Nelson J. Seven-day recall and other physical activity self-reports in children and adolescents. Med Sci Sports Exerc 1993;25:99-108.

29. Ainsworth BE, Haskell WL, Leon AS, Jacobs DR Jr, Montoye HJ, Sallis $\mathrm{JF}$, et al. Compendium of physical activities: classification of energy costs of human physical activities. Med Sci Sports Exerc 1993;25:71-80.

30. Hernández-Avila M, Romieu I, Parra S, Hernández-Avila J, Madrigal H, Willet W.Validity and reproducibility of a food frequency questionnaire to assess dietary intake of women living in Mexico City. Salud Publica Mex 1998;40:133-140.

31. Instituto Nacional de Salud Pública. Snut Sistema de Evaluación de Hábitos Nutricionales y Consumo de Nutrimentos. Cuernavaca Mor., México: INSP, 2003.

32. Grupo de Estudio de Insulinemia en Adolescentes. Concentración de insulina y lípidos séricos en adolescentes de preparatoria en Guadalajara, México. Salud Publica Mex 2003;45:SI03-SI07.
33. Jiang X, Srinivasan S, Webber L, Wattigney W, Berenson G. Association of fasting insulin level with serum lipid and lipoprotein levels in children, adolescents, and young adults: The Bogalusa Heart Study. Arch Intern Med 1995; 155(2):190-196.

34. Porkka KVK, Viikari JSA, Rönnemaa T, Marniemi J, Åkerblom HK. Age and gender specific serum lipid and apolipoprotein fractiles of Finnish children and young adults. The Cardiovascular Risk in Young Finns Study. Acta Pædiatr 1994:83:838-848.

35. Webber LS, Srinivasan SR, Wattigney WA, Berenson GS. Tracking of serum lipids and lipoproteins from childhood to adulthood. The Bogalusa Heart Study. Am J Epidemiol 1991;133:884-899.

36. Randle P, Garland P, Hales C, Newsholme E. The glucose fatty-acid cycle. Its role in insulin sensitivity and the metabolic disturbances of diabetes mellitus. Lancet 1963;: :785-789.

37. Hennes M, Shrago E, Kissebah A. Receptor and postreceptor effects of free fatty acids (FFA) on hepatocyte insulin dynamics. Int J Obes 1990; 14:829-830. 